DOI 10.15393/j10.art.2015.2465

\author{
ПРИЯОЖЕНИЕ \\ ИЗ ПИСЕМ Н. Д. ФОНВИЗИНОЙ (1850-1853) \\ Письмо Н. Д. Фонвизиной к И. А. Фонвизину \\ от 18-22 мая 1850 года
}

$\underline{\text { Мая } 18^{20} 1850^{20}}$

Пишу вамъ съ впрною оказіею другъ мой Братеиъ и потому могу обо всемъ откровенно бюспдовать. Вы какъ то писали, что напрасно я тревожусь предположеніемь бплаго знамя. Но вы вюрно меня не поняли. Если я избявила въ этомь случап опасеніе, то не за себя разумпется - потому, что я ни по какому случаю покуда не могу подпасть подъ знамя даже и ни за мужа, а говорила вообще за нашихъ. - Не всп впьь смотрять на вещи съ одинаковой точьки зргнія. - Чтобь судить о людяхъ и вешахъ совершенно справедливо - надо судить ихъ не по собственньмь чувствамь и убпжденіямъ но войти, такъ сказать, въ ихъ воззргнія, свое оставивъ при себг - смотрпьть какое на нихь вещи производять вліяніе. - Напр. иное бьло бь мнго счастьемъ; или по крайнпй мпрп я бь приняла за великую честь - а другому тоже положеніе тяжело до крайности и онь страдаеть оть него несказанно. Неужели же мнг не пожальть страждушаго и не искать облегчить его страданія потому только, что поставивъ себя на его мпстп, я бь страданія эти считала радостью? Господь судить внутреннее расположеніе человпка - и невозможно свои собственныя воззрпнія заставлять импть каждаго, или каждаго судить по своимь убюжденіямъ. - Тогда и сужденія и сочу<в>ствія наши къ людямб были бы слишкомъ односторонни. - Оть чего бы тяжко не страдаль человюкъ, но онб страдаеть а этаго уже достаточно <л. 1> для состраданія. Сказано просто: съ плачущими печальтесь съ радуюшимися радуйтеся - иначе не будеть мпьста Любви - пространной всеобъемлющ,ей. Если мь только по долгу христіанства, а не по чувству могучей любви будемь принимать участіе въ судьбахв страждушаго человпчества, то и участіе наше будеть холодно и не живо, потому, что мь свое будемь сравнивать съ чужимъ, и судить по себп - и разумпется держась своихъ убпжденій, судить строго. Тогда какъ въ подобныхъ случаяхв если Любовь заступаеть мпсто долга то о себп и своихъ собственныхъ убюжденіяхв забывается какъ то. - И странно - тогда то именно когда они какъ бы откидываются сердиемг въ сочувствіи его къ вовсе для него чуждому убпжденію и воззрпнію. - Чудодюйственная Сила Любви при этомъ самозабвеніи какъ бь дплаеть обмпнь - эти задушевныя убпжденія незамптнымб образомъ переливают <ся> въ сердияа которымъ сочувствуеть, просто, безъ всякаго нампренія образовать ихъ по своему. Такая Могучая Любовь 
разумпется не оть насъ и не наша но ни обитать ни поспияать даже не можеть серди, наши, если мь будемь крппко держаться за свое и по своему мгорилу вспхт мприть. - Недавно случилось мнг сойтись со многими страдальиами - совершенно какъ бь чуждымимнь по духу и убпжденіямб моимь сердечнымъ. Признаюсь что я даже не искала съ ними сближенія. - Другіе изъ нашихъ и Michel приняли дюятельное участіе <л. 1 об.> въ ихъ бпдствіяхъ. Снабдили вспмъ нужнымб - и сношенія сначала этимь только и ограничились. Между тюмъ они бьли предубюждень противъ вспхъ насъ и не хотпли даже принимать оть насъ помощи, многіе лишенные всего - считалинесчастьемь быть намб обязанными. Сочіализмь комунизмь фурьеризмъ бьли совершенно новымъ явленіемъ для прежнихъ Либераловъ и они дико какъ то смотрпли на новыя жертвы новыхъ идей. - Между тюмъ говорили о доставленіи майно денегъ Главному изб нихь Петрашевскому - который содержался вспхь строжпе - доступь ко вспмб къ нимб быль чрезвычайно труденъ. Я слушала все это равнодушно - даже признаюсь удивлялась своей холодности - и нюсколько упрекала себя - но какъ во мнг ничего нить хорошаго - собственно моего - то какъ нищая и успокоилась нищетою своею нравственною - негдю взять и дплать нечего - хлопоты и заботы другихь меня радовали. - Обрашағотся ко мнго съ вопросомъ: - не льзя ли мнгь попробовать дойти до бпднаго узника? - домъ нашь въ двухъ шагахъ оть острога. Не думавши много я отвючаю: «Если считають нужнымъ попробую»<.> Я даже не знала и не предполагала какъ это сдплать - возвратясь домой на меня вдругъ напала такая жалость такая тоска о несчастномь такъ живо представилось мню его горькое безотрадное положеніе - что я рпиилась подвергнуться вспмб возможнымб опасностямб лишб бъ дойти до него. Взявши $20 \infty$ сереб. я отьскала ладонку бисерную ${ }^{2}$ съ мошей - зашила туда деньги и образокъ <л. 2> привязала снурочикъ и согласила няню не говоря никому на другой день идти въ острогъ къ обпдни и попьтаться дойти до узниковъ - такъ и сдплали. У няни въ острогп есть ея знакомыцй - воспитанникъ Тальзина къ которому она иногда ходить. Мь послали арестанта позвать его въ Церковь - я посовптыввалась съ нимб. - Смотритель и семейство его бьли уже въ сношеніись нашими по случаю передачи съпстныхъ припасовъ, бюлья и платья нужнаго. - Оть начальства безпрерьвныя повторенія строгаго надзора. Отправивии нянина знакомаго для развюдыванія въ больнииу гдю быль Петрашев<скій>. - Я молилась - и предалась на всп изволенія Божіи - самое желаніе видпть узниковъ не иначе считая какъ Его внушеніемъ. Нянина знакомаго зовуть Кашкадамовь - онг возвратился говоря что можно попробовать дойти туда, подъ видомъ раздачи милостьни. Послю обюдни, какъ я запаслась

\footnotetext{
${ }^{1}$ Бьло очибочно: взявши (ред. испр.).

${ }^{2}$ Было очибочно начато: бир - исправлено автором: бисерную
} 
мелкими деньгами, - не подавая виду я объявила, что желаю раздать милостьню и отправилась прямо въ больницу. Боже мой въ какомъ ужасномь положеніи нашла я несчастнаго! - весь опутанъ желюзомъ, больной, истощенный. Покуда няня раздавала милостьню я надюла на него ладонку съ деньгами и обмпнялась нисколькими словами. Если онъ поразиль меня, то узнавъ мое имя и я его поразила. - Онб усппль сказать мнп многое но такое что сердие мое облилось кровью. Я не смпла показать ему моей скорби чтобь она не казалась ему упрёкомъ.. Онъ уже и такъ быль въ крайнгмъ бидствіи. Но насилу устояла на ногахъ оть горя не смотря на то не знаю оть куда взялась у меня нравственная <л. 2 об.> сила отвпчать спокойно на вопросы его, и искренно - право искренно благодарить его за участіе... Его пытали и самымб ужаснымб новоизобретпннымб способомб сльдь

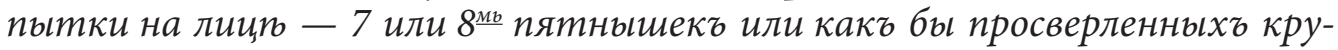
жечковъ на лбу - одни уже подсыхали другіе еще болюли иные были окаймлень струпиками - пальиь на правой рукю и на той же рукп полоса вдоль - какъ бь оть обозненія - въ холодной комнатп - на лбу безпрестанно проступала испарина крупными каплями, впки глазб по временамь страшно тргоптали<,> глаза разширялись<.> Онъ блюднюль въ это время какъ полотно, и потомъ опять принималь обыкновенный видъ свойвся нервная система какъ видно потрясена была до основанія. Его допраши-

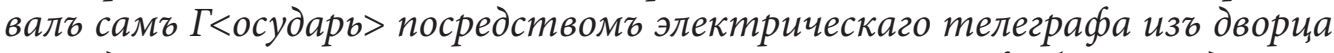
проведеннаго въ крппость. Но въ крппости къ телеграфу была придплана галваническая машина. - Я полагаю что его не то что пьтали - но при допросахъ, какъ онъ самъ расказываль намъ посль -онъ отвпчаль довольно смпло - не зная кто его спрашиваеть - вопроситель, видно разсердясь удариль по клавишамь и токъ машинь внезапно поразиль его. Онъ упаль безъ чувствъ впроятно на какія нибудь острыя снарядь пришелся лбомъ - и воть оть чего знаки налбу - анарукп - онъ очувствова <в>иись очутился ужезсидящемь на стуль и поддерживаемьй двумя - въ

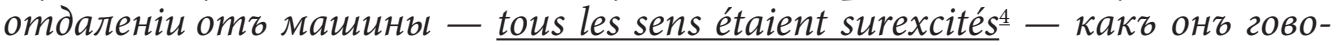
рить и ужасно томился жаждой. - Ему подали стаканъ водь но онъ замптивъ что въ водп что то какъ бь распускается <л. 3> и струйками соединяется съ водою - побоялся пить а при вспхъ опустиль въ стаканъ пальць и часть руки и вдругъ почувствоваль боль какъ оть обжога. Воть какія дюла! бюдньй человпкъ не можеть безъ трппюта объ этомъ говорить. - При одномъ воспоминаніи ужаснаго ошущенія онъ блюднпеть трясется и какъ бы входить въ изступленіе. - Ему кажется что пагубньй гальванической токъ, его и здюсь пресльдуеть; уже мь его успокоивали какь могли. Что за страшныя времена! То, что сказаль онь мнт, при перьвой встрпчп моей съ нимъ въ больнииль, относилось прямо ко мнп

\footnotetext{
${ }^{3}$ Было начато: в - исправлено автором: уже

${ }^{4}$ чувства переполняли (франи.)
} 
а не къ нему и поразило меня страшнымъ горемъ. Но Господь даль мнгь силь скрыть эту скорбъ отъ бгднаго страдальиа - который не смотря на свои заблужденія казался простодушнымъ какъ дитя. Фигурой и рпчью онъ напоминаеть покойника Никиту Мурав<вева> - тонг и манеры чрезвычайно любезные - и естественная доброта и чувствительность сердиа такъ и проглядывають въ неискуственной ргчи - тпмъ жалче мнть было огорчить его. - Оть него выила я - сама себя не помня, оть жгучей и давящей сердие скорби ивъ сопровожденіи Кашкадамова отправилась въ другія отдюленія для раздачи - пришли въ одну огромную удушливую и тёмную палату наполненную народомъ отъ стюсненія воздуха и сырости парь валиль какъ воть оть самовара. На противъ дверь съ замкомъ и при ней часовой. - Покуда няня говорила съ Кашкадам<овымъ> - у меня мелькнула мысль - я сунула ей деньги мелкія и сказавъ чтобы раздала выскочила и прямо къ часовому - «Отвори пожалоста я раздаю подаяніе»<.> Онг взглянуль на меня, вынуль ключь и къ великому <л. 3 об.> моему удивленію - отперг преравнодушно и впустиль меня. Четверо молодыхь людей вскочили съ наръ. Я назвала себя и спросила о именахъ ихъ - то были Сппшневъ - Григорьевъ - Львовъ и Толль. Сппшневъ прекрасныи и преобразованный молодой человпкъ. Григор<ьевъ > и Львовъ тоже премилые. Перьвый грустный и молчаливый - а второй живой маленькой и веселой. Толль претолстой молодой человпкь и по наружности кажется весьма ограниченнымб. Я усплась вмпстю съ ними и смотря на эту бюдную молод <о сть - слезы мои долго сдержанные прорвались наружу - я такъ заплакала что и они смутились и принялись утпшать меня. Но воть что странно - что они узнавъ что я оть Петрачевскаго - догадались о моей скорби тотчасъ - и не принимая нисколько на свой счеть утпшали меня въ моемъ горп. Это взаимное сочувствіе упростило сей часъ наши сношенія и мы какъ давно знакомые разболтались. Часовой за благо разсудиль запереть меня съ ними видя что я долго не выхожу. Няня между тпмг окончивъ свое дпло осталась съ Кашкад<амовымъ> въ спняхь разговаривать. Мнгь такъ было ловко и хорошо съ новыми знакомиами что я забыла о времени. Между тпмз смпна команды - и офицгорб новыи - часовой ни слова не говоря здаль ключь другому. Мь сльшиали шумг и говорь но не обратили вниманія - вдругъ шумъ усилился, сльшимъ отпирають и входятъ: дежурный офицпрг съ жандармскимъ капитаномъ. - Няня такъ испугалась что сдюлался понось - но подивитесь что ${ }^{6}<$ л. $4>$ я не только не испугалась но даже не сконфузилась - и привставъ поклонилась знакомому жандарму назвавь его по имени. - Мнг и мысли никакой не пришло о посльдствіяхъ. Жандармб ${ }^{7}$ потпрялся сталь разспрашивать о М. А.

\footnotetext{
${ }^{5}$ по - виисано.

${ }^{6}$ Было ошибочно: что что (ред. испр.).

${ }^{7}$ Было: Жардармъ - исправлено автором: Жандармъ.
} 
здоровьп я сказала что была у обпдни и зашла спросить у Господъ не нужно ли имг чего на дорогу. Онг удивлялся что я рано встаю - а я сказала что какъ я встаю рано то и посппваю всюду - и пошутивъ съ нимг простилась съ Господами сказавъ имъ до свиданья. Смольковъ жандармъ говориль мнгь послю, что моя смплость такь его поразила, что онб ргоиился содпйствовать намб - и сдпржаль слово. ${ }^{8}$ Этоть жандармб вспмб остальнымъ передаль тайныя деньги, вдпланныя въ книги, и показаль каждому какъ доставать и какъ опять заклюивать. - - Я было хотпла и къ посльднимъ пробраться но было уже поздно. - Возвратясь отдала отчёть въ моемъ похожденіи Мишелю. Онъ было потревожился но послю благодариль Бога что все такъ устроилось. Посль этаго намъ уже невозможно было не принимать живпйшаго участія во вспхх этихъ бюдныхъ людяхь и не считать ихъ своими. Дамы наши явились ко мнгь узнать удалось ли мнть доставить деньги. Мь положили подъ вечерг переодьвиись въ сопровожденіи няни пхать къ смотрителю. - Офицгрь быль изб кадетовъ и предобрый юнома. Туть же пріпхаль и одинъ изъ служащихь офицпровъ при строительной коммисіи - короткой пріятель Львову (теперь уже онб покойньй) иэтоть присоединился къ намъ въ желаніи видють узниковъ. Смотритель и обицирь согласились на нашу просьбу и сначала привели Петрашевскаго <л. 4 об.> одного. Онъ быль съ нами довольно долго - мы его угощали. Смотритель подчиваль чаемъ. Онб такъ сосредоточенъ въ себг что даже не зампчаеть что тоть. - Этаго увпли и привпли $4^{\underline{x}}$ съ которыми я сидюла взапертик,> ихъ не приказано было сводить вмпьсть съ Петрашевскимъ и съ тремя остальными - намб стало жаль что трое остальныхъ какъ бы покинуты. Становилось поздно и няня вздумала просить офицпра чтобы и остальныхъ привпли не уводя еще этихъ. Тоть взяль на свой страхъ. Вдругъ мы сльшемъ звукъ ияппей вспь вскочили и когда вочли съ крикомг бросились обнимать другъ друга описать вамъ восторга ихъ при неожиданномъ свиданіи другъ съ другомб невозможно. Мы всп просльзились и даже смотритель. Имъ столько было сообщить другъ другу, что мьг оставили ихъ на нюсколько времени и сами забились въ уголокъ - съ другомъ Львова<.> Поговоривъ и успокоившись они бросились къ намъ съ благодарностью ияловали намъ платье руки какъ обрадованные дгти. Одинъ изб послюднихъ троихъ Дуровъ

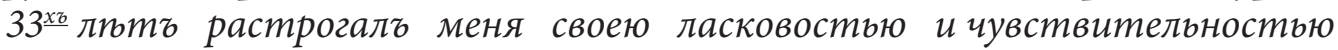
а няня просто рыдала. - Ей представилось что онъ какъ сынъ мой. - Онъ сказаль мнг что въ семействп быль не любимъ. Что можеть быть онъ самъ виною этому но что мать предпочитала ему сестеръ. Отець быль

\footnotetext{
${ }^{8}$ Далее следует авторский знак в виде звездь. Запись: Этоть жандармъ всъмъ остальнымъ передалъ тайныя деньги вдъланныя въ книги и показалъ каждому какъ доставать и какъ опять закльивать. - сделана на полях слева л. 3 под таким же знаком.

9 Далее было начато: д
} 
строгъ къ нему - быль Дядя и тотъ умеръ. <л. 5> Мать тоже умерла. Сестры замужемъ но не любять его - а двоюродный его брать Ростовцевъ судиль по судамь его, и теперь у него ртьшительно нгть ни одной родной души. Онг еще сказаль мнть что онъ всегда помниль какъ одна изъ нашихъ дамъ Княгиня Волконская маленькаго его ласкала что это были единственныя ласки которыя онб помнить во время дютства своего - и что онб узнавъ осужденіе свое въ Сибирь пххаль съ надеждою встртттить гдю нибудь Княгиню. Мь уже знали что онъ и Достоевской осуждены на крппостныя работы въ Омской крппости и съ Княгиней поэтому нпть надежды ему свидються - у меня мелькнула мысль и я туть же сообщила ${ }^{10}$ её ему. Я предложила ему быть для него тпмъ, чюмъ была Княгиня выдать его за родственника, котораго я помню маленькимь - и такимь образомь быть ему сколько нибудь полезной. - Можете вообразить съ какою радостью и благодарностью приняли мое предложеніе присудствующія точно удивлялись что Д<уровъ> особенно какъ то все со мною какъ старинный знакомьй и даже спросили объ этомъ - тутъ же и объявили мы вспмъ положенное между нами тайно ${ }^{11}$. Теперь во вспй Сибири особенно въ Тобольскп и Омскп никто въ нашемъ родствп съ Дур<овымъ> не сомнпвается. Мишель няня да еще одна особа а именно Маша Францова только въ секретп, всть прочія даже изб нашихъ принимають родство <л. 5 об.> за чистья деньги. Передъ зарей т. е. когда вечеромъ бъютъ зорю12 мы возвратились домой но я продолжала поспщать племянника и мнг уже не препятствовали - всп официры наперерывъ давали свиданія не только съ Дур<овымъ> но и со вспми его товарищами<.> Жандармской Капит<анъ> предложиль даже М. А. за рпккою при отправленіи Дур<ова > и Достоев<скаго > импть съ ними свиданье и мы пьзили. Я жандармовъ просила беречь дорогой Господъ. Мьь въ Омскъ писали и рекомендовали бгдныхъ друзей нашихъ какъ въ родственникп нашемъ такъ и въ товарищь его многіе теперь въ Омскп принимають участіе - доставляють даже по временамь ему мои посланія и оть него ко мнть. Я по иялльмь часамъ въ бытность ихъ здюсь съ ними бпспдовала. Не искала я нисколько перелить въ нихъ мои ${ }^{13}$ задушевныя убюжденія. - Но Господь такую нюжную материнскую Любовь къ нимъ влиль въ мое сердие что и въ ихъ сердия это отразилось. Они прежде имтли разныя противленія. Дур<овъ $>^{14}$ особенно оть родственныхъ связей. - Религіозное начало я въ нихъ и сначала зампчала но оно было не отчетливо перепутано разными новыми воззрпніями. -

\footnotetext{
${ }^{10}$ Было: соббщила - исправлено автором: сообщила

${ }^{11}$ тайно - вписано.

${ }^{12}$ т. е. когда вечеромъ бьютъ зорю - вписано.

${ }^{13}$ Далее было начато: д

${ }^{14}$ Дур <овъ $>-$ вписано.
} 
Теперь пишуть мнгь оть туда, да изъ Дур<ова> писемъ видно что онъ много измпнился. Одностороннее греческое или правильнпе руское Православіе кот<орое> смпиивали съ Христіанством⿰ - и разумпется вб этомб тпсномг воззргоніи отрицала. Теперь все это приходитг въ порядокъ я прямо сказала имъ что я Христіанка по убпжденію но не стпсняюсь <л. 6> формами Православія, самодержавія и народности. Терплю потому, что и Богъ еще терпитъ все это. "Que je ne suis ni pour la souveraineté des Rois - ni pour celle des peuples mais bien pour la souveraineté de Dieu que j'espere et attend d'après les propheties et la promesse du Seigneur. - Что даже все, что теперь дюлается въ Мірг, кажется мнп средствами ведущими къ той же иълли и потому меня ничто не смущаеть ничто не удивяеть - я вижу во всемъ Промысль и руку Премудрости Божіей». - И точно: вспьхъ предаль въ непослушаніе чтобы вспхъ помиловать. Говорить Апостоль. Но нашему глупому естественному разуму не подъ силу постигнуть этой тайнь. Счастливы избранные въ жертву - Страждущіе. Это говорю я по частному моему глубоко внутреннему убижденію. - Горе же ищущимь Своихъ си - кто бы они ни были. Святую Истину приходится отрывать вб Землю - иочищать изб множества дрязгу. - Человпчество какъ и человпкъ страданіемъ научается Послушанію<.> - Кажется какъ просто узнать Истину импя Евангеліе но какъ вникнешб ${ }^{15}$ въ глубину нравственнаго паденія человпка дюлается яснымъ, что усвоеніе массами этой простой святой Истинь, этаго закона Любви, весьма трудно и недоступно человпческимъ усиліямъ. Надо чтобы массы пришли въ нпкоторое единство воззрпній и стремленій - чтобы разнородное - составляющее Единищь или Индивидуи, въ каждомь измпнилось и приняло <л. 6 об. $>16$ общій колорить и направленіе - въ началь Христіанства Сомествіе Св. Духа совершило чудо это вдругъ надъ многими - и при томъ совершило окончательно - просвптивъ иосвятивъ избранныхъ. Это событіе было Проявленіемь Всемогущества Божія - Слюдствіемь и силою Искупленія и залогомь будущаго. - Посль повторялось и повторяется надъ лииами вюрю и уповаю что будеть время когда по пророчеству тоть же Духъ прольется и на всю Церковь. Но какъ это будеть дпйствіе окончательное нашего спасенія - то человпчество (какъ ичеловпкъ) должно быть пріуготовлено кв принятію и усвоенію Духа истины. Сколько было уклоненій и тьмы въ массахъ народныхъ составляющихъ Христіанство посль перьваго Свпта Апостольскаго. Духъ въ этихъ массахъ заглушенъ быль Плотію. - Душа одна проявлялась. - Теперь человпчество не смотря на всп его заблужденія и проказы сдплалось духовнюе - слюдовательно и способнпе къ сообщенію съ Духомъ Истинь. - Пускай тайна беззаконія зргеть но дголо Божіе видимо и быстро въ эти послюднія времена идеть

\footnotetext{
${ }^{15}$ Было: вникнещъ - исправлено автором: вникнешъ

${ }^{16}$ Далее поставлен авторский знак: ${ }^{\circ \circ}$. На л. 7 под таким же знаком продолжение записи.
} 
впередъ - и Путь Господу Симъ Единому Сущему - Единому ${ }^{17}$ Импющему Державу и власть, уравнивается<.> Мудрено ли что все высящееся низпадаеть всп горы и холмы - превращаются въ долины. Вг этихъ переворотахъ <л. 7> иявленіяхъ можеть $л и^{18}$ сохраниться порядокъ, тишина и спокойствіе? - И удивляться нечему и судить мудрено - особенно по своимб собственнымб ${ }^{19}$ убпжденіямб - весьма тпоснымб и ограниченнымб. Поднявшись надъ самимъ собой и взглянувъ съ высоть все яснпе кажется но зато голова кружится. О какая бездна Премудрости и впденія Божія! Сколь неисповпдимы судьбы Твои! и неизслпдимь Пути Твои! - вспххь предаль въ непослушаніе чтобы вспхт помиловать! - Дикими кажутся идеи Свободы равенства братства и другіе второстепенныя для привыкшихъ къ своимб усвоиннымб разумомб идеямб; особенно если расматривать эти идеи въ томг колоритг который дають имб ${ }^{20}$ многіе теперешнія общества или придавая имь краску собственнаго разума. Но идеи эти истекають отъ вючной Истины и Господь перьвый возвпстиль о нихъ людямб<.> Человпкъ созданъ быть независимымъ оть земнаго и Свободу свою утраченную уклоненіемъ оть Бога обрптаеть во Христю. Равенство находить въ Немъ же вступая въ настоящее значеніе человпка. Братству научаеть Его Святая державная и всеобъемлющая Любовь дюлающяаяся его Жизнію и дающая Жизнь вспмг подобнымъ Ему. Образб по которому <л. 7 об.> всп созданы дюлаеть ${ }^{21}$ вспхх равными а Любовь и Усыновленіе чрезъ страданіе Сьна Божія вспхъ братьями. Жизнь же Слова таящаяся въ духп каждаго человпка должна бы вспхъ освободить. Лицамъ доступно почерпать все это въ Евангеліи но массамь предоставлено страданіями усвоивать эти идеи - тоже и о тицахь сказать можно но страданія лиць въ массахъ не замптны за то страданія массъ для лиць весьма ощутительны - и всегда болье проявляются въ наружныхъ переворотахъ тогда какъ частныя перево <ро>ты въ тииахв часто для самихъ этихъ лиць остаются тайными. - Сколько мнгь разъ случалось чуждаться людей. По предубюжденіямь составишь себг понятіе, по какимь нибудь даннымъ, о

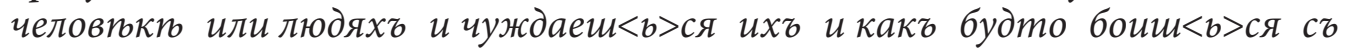
ними сближенія - случайно сблизиш <ь $>$ ся - и найдешь непремпнно нпчто родственное - да даже кажется нпть человпка въ которомъ бы не могъ найти этаго развп уже человпкъ какой двуличневый съ основнымъ съ намтреннымъ лукавствомъ - въ которомъ образъ Сотворенія, образб Божій, такъ глубоко скрытъ и такъ тщательно замаскированъ образомъ непріязненнымъ, что и не доберется до него - и это всегда какъ то болез-

\footnotetext{
${ }^{17}$ Единому - вписано.

${ }^{18}$ ли - вписано.

${ }^{19}$ Далее было начато: сужде

${ }^{20}$ имъ - вписано.

${ }^{21}$ Было: дълаютъ - исправлено автором: дълаетъ
} 
ненно чувствуешь. - Мнг случалось всего чаще такую неискренность общенія встрпчать въ людяхъ по видимому набожныхъ - что я приписьваю <л. 8> въ нихъ привычкп облекаться въ извпстную нравственную борму - весьма стпснительную въ общеніяхъ духовныхъ. Напр. въ форму смиренія - молчаливости и проч. Форма вещь по моему пустая и вовсе не сушность дпла. Что до меня касается я ненавижу бормь - да и не усидють мнг ни въ какой - сей часъ - перельюсь черезъ край и тогда кончено хорошо если бы я была какъ чистая вода а то мутная грязь - воть почему не совсемъ то пріятно и я понимаю что меня нельзя находить любезною но что же дплать? Пречистое Слово видить и знаеть меня грязюю - а людей не стоить и обманывать прикидьваясь чюмъ то другимъ или для приличія скрываясь въ формы благообразныя. Желала бы я знать получиль ли Дмитрій длинное письмо мое. Миша писаль что оть $24^{2 о}$ Января получиль. - Я въ тоже время какъ заготовляла длинное писала и особое къ Мишп и тогда же отправила. На него то вюроятно и отвпчаеть онъ такимб грустнымб письмомб. Боюсь чтобы мое длинное посланіе не разстроило Миши. Но мнг необходимо бьло поговорить съ нимб откровенно; мь такъ долго не понимали другъ друга! Случайно все тёмное объяснилось, и я не могла молчать. Теперь еще пишу и прошу васъ сердечныци другъ мой доставить Митп и Мишп здюсь прилагаемое на ихъ имя - но съ нпкоторою предосторожностью - не надо чтобь это письмо попалось. - - Простите если наскучила вамб длиннымб письмомб какъ расписалась! Послюдній изб привезенныхъ быль 22 Момбелли - славный молодой человпкъ но болезненный. М. А. выпзжаль за рпку съ нимъ беспдовать а я на сто<? $>^{23}<$ л. 8 об.>

Онъ за болезнію быль остановленъ здюсь на двю недпли и я всякой день съ нимг видплась въ острожной больницп. Мню припомнилось теперь что намъ говориль покойныци Алтайской Макарій - когда онъ хлопоталь чтобы напечатать по руски Библію и спрашиваль оть чего запрещено перепечатываніе Новаго Завпта - въ Синодп ему отвючали потому-что въ Св. Писаніи находятся многіе опасныя мпста - идаже въ Новомь Завпть какь напр. слова: Упразднить всякое начальство и власть. Опасно чтобы читающимб не подало мысли о упраздненіи власти. Ма<ка>рій отвпчаль: но если это слово пророческое. Оно всячески исполнится. Ему

22 Далее следует авторский знак: /// Запись: Момбелли - славный молодой человъкъ но болезненный. М. А. выъзжалъ за рбку съ нимъ бесьдовать а я на сто<?> - сделана на полях слева под таким же знаком, далее запись не прочитывается: край листа загнут.

${ }^{23}$ На полях л. 8 об. следует авторский знак: Запись: Онъ за болезнію былъ остановленъ $\infty$ когда онъ хлопоталъ чтобы напечатать - сделана на полях слева л. 8 под таким He .

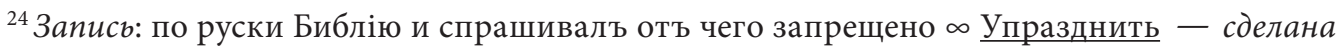
на полях слева л. 7 об. под знаком ө. 
отвичали: такъ - но не надо ч<итать. $>^{2526}$ Объ этомъ пророчествп знали - по славянски не такь понятно и при томь въ чтеніи церковномь незамптно а читая скорпе до смьсла дойдешъ. На Макарія посль того дулись. Простите мой сердечный другъ ${ }^{27}$ всемъ сердиемъ васъ обнимаю изб Омска ещце не импю отвпта оть Княгины на Туркинскія водь я и ей писала о Дуровю - и она хлопотала. Осужденные на каторгу не работають содержатся какъ ${ }^{28}$ наши въ тюрьмп, въ Акатуг - всп пятеро вмпсть Толль въ заводп и Ястржемской въ заводп на здпинее начальство - т. е. Князь изг трусостиличной - прескверно поступаеть съ этими бпдными<.> ${ }^{29}$ Такія мелочныя строгости что изъ рукъ вонъ - а Муравъевъ напротивъ - о бьдныхъ здпшнихв полякахв и говорить нечего ихъ спкуть и бьють какъ негровъ. Еще какъ Богъ храниль оть возмущенія! ${ }^{30}$ Прошиаите другъ мой. Милаго друга Екатерину Өедоровну обнимаю Александру Өедоровну привптствую<.> Мих<аилу> Иван<овичу> усердно кланяюсь. Васъ оть всего сердиа обнимаю. Сестра и другъ вашъ Н. Ф.

$22^{2 о}$ Мая. Сегодня получила изъ Омска письмо оть Князя и Княгины полагаю что въ отвпть на мое о Турк. вод. - видно уловка моя удалась вполнп! Хотя о вод<ахъ> не говорить ни слова но все письмо ${ }^{32}$ наполнено увпреніями дружбы и преданности. Полагаю что Князь - написаль уже

25 Лист поврежден, слово прочитано предположительно.

${ }^{26}$ Запись: всякое начальство и власть. Опасно чтобы читающимъ не подало мысли о упраздненіи власти $\infty$ но не надо ч<итать.> - сделана на полях слева л. 7 под авторским знаком. Далее следует другой авторский знак. Запись на полях слева л. 5: Объ этомъ пророчествъ знали $\infty$ Простите мой сердечный другъ - сделана под таким же знаком.

27 Далее в основном тексте следует авторский знак: Ф. Запись: всемъ сердцемъ васъ обнимаю $\infty$ Осужденные на каторгу не работаютъ содержатся какъ - сделана на полях слева л. 6 об. под таким же знаком.

${ }^{28}$ Далее следует авторский знак. Запись: наши въ тюрьмъ, въ Акатуб $\infty$ прескверно поступаетъ съ этими бъдными - сделана на полях слева л. 6 под таким же знаком.

${ }^{29}$ Далее следует авторский знак. Запись: Такія мелочныя строгости что изъ рукъ вонъ а Муравьевъ напротивъ - о бъдныхъ здъшнихъ полякахъ и говорить нечего ихъ съкутъ и бьютъ какъ негровъ. Еще какъ Богъ хранилъ отъ возмущенія! - сделана на полях слева л. 5 об. под таким же знаком.

${ }^{30}$ Далее следует авторский знак. Запись: Прощайте другъ мой. Милаго друга Екатерину Өедоровну обнимаю - Александру Өедоровну привътствую<.> Мих. Иван. усердно кланяюсь. Васъ отъ всего сердца обнимаю. Сестра и другъ вашъ Н. Ф. - сделана на полях слева л. 4 об. под таким же знаком.

31 Запись: 22 Мая. Сегодня получила изъ Омска письмо отъ Князя и Княгины полагаю что въ отвЂтъ на мое о Турк. вод. - видно уловка моя удалась вполнъ! Хотя о вод<ахъ> не говорить ни слова но все письмо - сделана на полях слева л. 1.

32 Далее следует авторский знак: . Запись: наполнено увъреніями дружбы и преданности. Полагаю что Князь - написалъ уже обо мнъ въ Петер<бургъ> - сделана на полях слева л. 2 об. под таким же знаком. Далее следует другой авторский знак. Под этим 
обо мнгь вг Петер<бургъ> и хочеть сдплать мнгь сюрпризб. - Увидимъ что будеть! - Простите. ${ }^{33}$

\section{Текстологическая справка}

Полностью публикуется впервые. Источник: НИОР РГБ. Ф. 319.1.13. Текст письма приводится в авторской орфографии и пунктуации. В тексте и на полях письма имеются неавторские пометы и подчеркивания карандашом.

Частично опубликовано в изданиях: Житомирская С. В. Встречи декабристов с петрашевцами // Литературное наследство. Т. 60. Декабристылитераторы. М.: АН СССР, 1956. [Ч.] II. Кн. 1. С. 618-622; Громыко М. М. Сибирские знакомые и друзья Ф. М. Достоевского. Новосибирск: Наука, 1985. С. 75-80; Захаров В. Н. Достоевский в Тобольске // Тобольск и вся Сибирь. 425 лет Тобольску. Альманах № 18. Тобольск, 2012. С. 72-81; Захаров В. Н. Имя автора - Достоевский. М.: Индрик, 2013. С. 159-161.

Подготовка текста и публикация - Е.Н. Вяль, примечания Л. В. Алексеевой.

\section{ПРИМЕЧАНИЯ}

С. 55. ...о доставленіи тайно денегъ Главному изъ нихъ Петрашевскому - Михаил Васильевич Петрашевский (Буташевич-Петрашевский) (13.11.1821-19.12.1866) - утопический социалист, организатор «пятниц», окончил Царскосельский лицей, учился на юридическом факультете Петербургского университета, титулярный советник, служил переводчиком в Департаменте внутренних сношений Министерства иностранных дел. С 1844 г. организовал собрания, которые стали проходить еженедельно по пятницам. Арестован в ночь на 23 апреля 1849 г., приговорен к расстрелу за преступные замыслы о ниспровержении государственного строя, по конфирмации осужден на бессрочную каторгу. 22 декабря 1849 г. с Семеновского плаца отправлен через Тобольск в Шилкинский завод, где пребывал с 1850 по 1854 гг., затем в Акатуй (см.: Венгеров С. Петрашевцы // Энциклопедический словарь: в 41 (82+4 дополн.) т. / издатели: Ф. А. Брокгауз и И. А. Ефрон. СПб.: Типо-Литография И. А. Ефрона, 1898. Т. XXIII (45). С. 450-452).

С. 55. ...привязала снурочикъ и согласила няню - Имеется в виду Матрена Петровна Нефедова - няня Н. Д. Фонвизиной (Апухтиной), добровольно последовавшая за ней в Сибирь. Упоминается по имени в письме И. Кашкадамова к Н. Д. Фонвизиной от 27 апреля 1852 г. (НИОР РГБ. Ф. 319.2.34).

С. 55. ...воспитанникъ Тальзина - Иван Дмитриевич Талызин (1799-14.05.1844) действительный статский советник, капитан, адъютант правителя Кавказа генерала А. П. Ермолова, Тобольский, а впоследствии Оренбургский гражданский губернатор (1841-1844).

знаком на полях слева л. 2 сделана запись: и хочетъ сдълать мнъ сюрпризъ. - Увидимъ что будетъ! - Простите. - под таким же знаком.

33 Записи: Онъ за болезнію былъ остановленъ здъсь $\infty$ Увидимъ что будетъ! - Простите. - сделаны на полях лл. 1-8. 
С. 55. ...Нянина знакомаго зовуть Кашкадамовъ - Ипполит Кашкадамов - служитель Тобольской пересыльной тюрьмы. Б. Н. Тихомиров высказывает гипотезу о том, что неосуществленный замысел 1864 г. Ф. М. Достоевского «Кашкадамов» восходит к тобольским впечатлениям писателя (см.: Тихомиров Б. Н. Неосуществленный замысел Достоевского «Кашкадамов» (материалы к гипотезе) // Достоевский и современность: материалы XXVI Международных Старорусских чтений 2011 года. В. Новгород, 2012. C. 376).

В архиве Н. Д. Фонвизиной (НИОР РГБ. Ф. 319) хранятся письма И. Кашкадамова: к Н. Д. Фонвизиной от 27 апреля 1852 г. (ф. 319.2.34) и к М. А. Фонвизину (ф. 319.2.35) от 3 мая 1852 г. с приложенной к нему запиской от 3 мая 1852 г. Из писем следует, что Кашкадамов был подвергнут суду и наказанию за неустановленное упущение по службе, каким мог быть, например, побег заключенного. В письмах Кашкадамов благодарит Фонвизиных за их участие к нему, высказывает свои пожелания отбывать наказаниев каком-либо из местных тюменских заводов, надеясь в будущем на вольное поселение по причине болезни, но при этом не желает быть униженным или причинить неудобство кому-либо из многочисленных знакомых на Успенском заводе.

С. 57. ...напоминаетъ покойника Никиту Мурав<вева> - Никита Михайлович Муравьев (1796-1843) - сын писателя и публициста Михаила Никитича Муравьева и Екатерины Федоровны (урожд. Колокольцовой), декабрист, капитан Гвардейского генерального штаба, содействовал образованию Союза спасения, Союза благоденствия. В 1820 г. высказывал идею установления республиканской формы правления путем проведения вооруженного восстания. В 1821 г. им было организовано Северное общество. 23 декабря 1825 г. был арестован по обвинению в причастности к работе тайного общества. 26 декабря помещен в Петропавловскую крепость, осужден на 20 лет каторжных работ, срок которых сокращен до 15 лет. Жена Никиты Муравьева, Александра, отправилась вместе с мужем в Сибирь. С 1836 г. пребывал в Иркутске, где и скончался в 1843 г.

С. 57. ...то были Сппшневъ - Григорьевъ - Львовъ и Толль - Николай Александрович Спешнев (1821-29.03.1882) - общественный деятель, один из участников «пятниц» М. В. Петрашевского, входил в кружки Н. С. Кашкина, С. Ф. Дурова, бывал на собраниях А. Н. Плещеева. В ночь на 23 апреля 1849 г. Спешнев был арестован и приговорен к смертной казни, замененной десятью годами каторги. 23 декабря 1849 г. Спешнев отправлен в Тобольск, затем в Александровский завод Нерчинского округа. В конце 1857 г. был назначен начальником газетного стола Иркутского губернского правления. В начале 1860 г. генерал-губернатор Восточной Сибири Н. Н. Муравьев увез Спешнева в Петербург, где ему было возвращено дворянство. Впоследствии поселился в своем имении в Островском уезде Псковской губернии.

С. 57. ...mо были Сппшневъ - Григорьевъ - Львовъ и Толль - Николай Петрович Григорьев (1822-1886) - поручик лейб-гвардии конно-гренадерского полка, сын Петра Богдановича Григорьева, полковника Преображенского лейб-гвардии полка, позднее генерала-майора, активный участник собраний у М. В. Петрашевского, затем у С. Ф. Дурова, участвовал в подготовке изданий для подпольной типографии, стал автором агитационного рассказа «Солдатская беседа», зачитанного в апреле 1849 г. у Н. А. Спешнева. В ночь на 23 апреля 1849 г. арестован, 22 декабря 1849 г. приговорен к расстрелу, замененному 15 годами каторжных работ, отправлен в Шилкинский завод Нерчинского округа. В результате обострившегося у него психического заболевания в 1857 г. отдан под надзор семьи и жил в Нижнем Новгороде. 
С. 57. ...mо были Сппиневъ - Григорьевъ - Львовъ и Толль - Федор Николаевич Львов (23.08.1823-04.06.1885) - штабс-капитан Егерского лейб-гвардии полка, мемуарист, публицист, посещал «пятницы» Петрашевского, участвовал в кружках С. Ф. Дурова и А. И. Пальма. Арестован 29 апреля 1849 г., смертная казнь заменена 12 годами каторжных работ, которые он отбывал в Шилкинском, затем в Александровском, в 1854 г. - в Нерчинском заводах. По манифесту 26 августа 1856 г. Львов выпущен на поселение и стал служить в Главном управлении Восточной Сибири в Иркутске. В 1862 г. ему было разрешено жить во внутренних губерниях. Генерал-губернатор А. А. Суворов добился для него разрешения жить в столицах и устроил его на службу. В 1870 г. был избран секретарем «Русского технического общества».

С. 57. ...mо были Сппиневъ - Григорьевъ - Львовъ и Толль - Феликс Густавович Толль (1823-1867) - писатель, педагог, по окончании педагогического института был преподавателем русской словесности в астраханской гимназии, затем в Финляндском корпусе, впоследствии в Главном инженерном училище, преподавал историю в школе военных кантонистов. С 1846 г. посещал собрания у М. В. Петрашевского. Арестован в ночь на 23 апреля 1849 г. «За порицание религии» Толль был приговорен к смертной казни, которую заменили двумя годами каторги. После каторги поселился в Томске, где сблизился с М. А. Бакуниным. В 1857 г. Толлю возвращены права дворянства, а с 1859 г. разрешено жить в столице.

С. 57. ...сталь разспрашивать о М. А. - Имеется в виду Михаил Александрович Фонвизин (31.08.1788-12.05.1854) - брат декабриста Ивана Александровича Фонвизина, мужа Фонвизиной Натальи Дмитриевны (урожд. Апухтиной, во втором браке Пущиной). Генерал-майор в отставке, участник Отечественной войны 1812 г. и заграничных походов, член Союза благоденствия и Северного общества. Был арестован по делу декабристов, осужден на 8 лет каторги. С 1828 г. в Нерчинских рудниках, с 1832 г. на поселении в Енисейске, Тобольске. 13 февраля 1853 г. ему было разрешено вернуться на родину и жить в имении брата Марьино Бронницкого уезда Московской губернии под строжайшим полицейским надзором и воспрещением въезда в Москву и СанктПетербург. 15 апреля 1853 г. он выехал из Тобольска, в Москву прибыл 11 мая 1853 г., отправлен с жандармом в Марьино 12 мая 1853 г.

С. 58. ...Одинъ изъ посльднихъ троихъ Дуровъ - Сергей Федорович Дуров (181618.12.1869) - поэт, прозаик, переводчик. В 1843-1849 гг. вел активную литературную деятельность, состоял на службе. После выхода в отставку в 1847 г. стал участником собраний у Петрашевского, организовал литературно-музыкальный салон. В ночь на 23 апреля 1849 г. был арестован и приговорен к смертной казни, которую заменили четырехлетней каторгой. Вместе с Достоевским отбывал наказание в Омском остроге. После каторги был отправлен рядовым в Петропавловск, год спустя был переведен в гражданскую службу, в 1857 г. получил разрешение вернуться в Европейскую часть России.

С. 59. ...двоюродный его братъ Ростовцевъ - Яков Иванович Ростовцев (09.01.1804 18.02.1860) - граф, известный деятель крестьянской реформы, генерал от инфантерии, окончил Пажеский корпус. Отец его был директором училищ С.-Петербургской губернии. Я. И. Ростовцев приходился С. Ф. Дурову родственником (из письма следует - двоюродным братом). 12 декабря 1825 г. сообщил о заговоре, не назвав имен, будущему Николаю I. Вместе с А. Ф. Голицыным, Л.В.Дубельтом, П.П.Гагариным, В.А.Долгоруковым, И. А. Набоковым Я. И. Ростовцев входил в Следственную комиссию по делу петрашевцев. 
С. 59. ...одна изъ нашихъ дамъ Княгиня Волконская - Мария Николаевна Волконская (1805-22.08.1863) - княгиня, дочь героя 1812 года Н. Н. Раевского, правнучка М. В. Ломоносова, жена декабриста князя Сергея Григорьевича Волконского, разделившая с ним ссылку в Сибирь. Вместе со своей подругой Е. И. Трубецкой Мария Николаевна оказывала помощь не только своему мужу, но и остальным узникам. В конце 1827 г. декабристов перевели в Читу, куда в январе 1828 г. приехала Н. Д. Фонвизина. В 1845 г. Волконскому позволили жить в Иркутске, с 1847 г., после назначения генералом-губернатором Н. Н. Муравьева, положение семьи облегчилось, при Александре II последовала амнистия, и Волконский с семьей вернулся на родину.

С. 59. ...еще одна особа а именно Маша Францова - Мария Дмитриевна Францева (1827-1917(?)) - дочь тобольского прокурора Д. И. Францева, воспитанница Фонвизиных. Оставила воспоминания о пребывании петрашевцев в Тобольске (Францева М. Д. Воспоминания // Исторический вестник. 1888. Т. 32. № 5. С. 381-412; № 6. С. 610-640; № 7. С. $61-87 ;$ 1917. Т. 147. № 3. С. $694-715)$.

С. 62. ...nолучиль ли Дмитрій - Имеется в виду сын Михаила Александровича и Натальи Дмитриевны Фонвизиных Дмитрий Михайлович Фонвизин (26.08.182430.10.1850) - студент Петербургского университета, замешанный в деле петрашевцев. Был болен туберкулезом. Его отъезд на Кавказ по совету Боткина для лечения туберкулеза спас его от ареста.

С. 62. ...Послюдній изъ привезенныхъ былъ Момбелли - Николай Александрович Момбелли (24.02.1823-27.12.1902) - поручик лейб-гвардии Московского полка, с осени 1848 г. посещал «пятницы» М. В. Петрашевского, принимал участие в собраниях у С. Ф. Дурова, был арестован в ночь на 23 апреля 1849 г., приговорен к расстрелу, замененному 15 годами каторги, из-за болезни отправлен в Тобольск позже других осужденных (12 января 1850 г.). Отбывал каторгу в Александровском сереброплавильном заводе Нерчинского округа. По манифесту 26 августа 1856 г. вышел на поселение, отправился рядовым на Кавказ, за отличие в боях в 1859 г. был произведен в прапорщики. По амнистии 1856 г. был отправлен рядовым на Кавказ. В 1859 г. произведен в офицеры, в 1865 г. получил чин майора.

С. 62. ...nокойныцй Алтайской Макарій - Макарий Алтайский, архимандрит (в миру - Михаил Яковлевич Глухарев) (10.11.1792-30.05.1847) - православный миссионер, один из переводчиков Библии на русский язык. В 1829 г. получил назначение в Тобольскую епархию. По благословению митрополита Московского Филарета (Дроздова) начал обращать в православие живущие на Алтае тюркские народы. В 1983 г. причислен к лику святых, его имя внесено в Соборы Сибирских, Смоленских и Костромских святых. Его перевод Ветхого Завета был посмертно опубликован в журнале «Православное обозрение» (1860-1867) и использовался при работе над синодальным переводом Библии.

С. 63. ...не импю отвпта отъ Княгинь - Имеется в виду Наталья Дмитриевна Горчакова (Черевина) (?-31.08.1849) - жена генерал-губернатора Западной Сибири Петра Дмитриевича Горчакова, кавалерственная дама ордена Св. Екатерины.

С. 63. ...на Туркинскія воды - Имеются в виду Туркинские минеральные воды (в настоящее время бальнеологический курорт «Горячинск» в 188 км от Улан-Удэ) - горячие минеральные воды в Забайкальской обл., Баргузинского окр. на юго-восточном берегу Байкала. Первый минеральный источник в Забайкальской области. Курорт открыт в 1751 г. В нач. XIX в. горячий минеральный источник был довольно известным курортом. 
1830-1840 гг. ознаменованы пребыванием на курорте декабристов с семьями. На водах бывали декабристы И. И. Пущин, С. Г. Волконский, К. П. Торсон, Ф.Ф. Вадковский, А. П. Барятинский, Д. А. Щепин-Ростовский, А. З. Муравьев и др. В опубликованном С. В. Житомирской отрывке из письма допущена ошибка: «...Из Омска еще не имею ответа от княгини на Тункинские (курсив мой. - Л. А.) воды» (см.: Житомирская С. В. Встречи декабристов с петрашевцами // Литературное наследство. М.: Наука, 1956. Т. 60. Кн. 1. С. 622). Ошибка могла возникнуть по созвучию с другим минеральным источником Забайкалья (их насчитывается до 400), расположенным на территории нынешнего Тункинского национального парка Бурятии в районе Восточных Саян и Тункинской котловины.

С. 63. ...наши въ тюрьмп, въ Акатую - Акатуй - село, в котором с 1832 по 1917 гг. располагалась каторжная тюрьма (в 625 км от Читы при Акатуйском руднике Нерчинского горнозаводского округа). Труд каторжан заключался в добыче свинцово-серебряных руд. Среди политических заключенных в тюрьме содержался декабрист М. С. Лунин, участники польских восстаний $1830-1831,1863-1864$ гг.

С. 63. ...Ястржемской въ заводю - Иван (Фердинанд) Львович Ястржембский (18141880 -е гг.) - титулярный советник, с мая 1848 г. посещал собрания М. В. Петрашевского, был арестован в ночь на 23 апреля 1849 г. за свои рассуждения о религии, правительстве, за чтение своих сочинений о политической экономии и статистике. Приговорен к смертной казни, которая была заменена шестью годами каторги. 24 декабря 1849 г. был отправлен в Тобольск, из Тобольска - в винокуренный завод Тарского округа. По манифесту 26 августа 1856 г. Ястржембский вышел на поселение, в 1857 г. ему было возвращено дворянство.

С. 63. ...Князь изб трусости личной - Имеется в виду Петр Дмитриевич Горчаков (05.07.1789-18.03.1868) - князь, генерал-губернатор Западной Сибири в 1850-1853 гг. 18-20 января 1850 г. Горчаков отдал распоряжение об отправке петрашевцев из Тобольска по назначенным местам на почтовых лошадях. Принимавшая горячее участие в делах петрашевцев М. Д. Фонвизина, находясь в дружеских отношениях с Горчаковым, просила его оказать содействие посланным в Омск Достоевскому и Дурову. После размолвки с Н. Д. Фонвизиной со стороны Горчакова начались притеснения петрашевцев.

С. 63. ...Милаго друга Екатерину Өедоровну обнимаю - Имеется в виду Екатерина Федоровна Пущина (род. 1771-1831 - ум. после 1854(?)) - сестра жены Ивана Александровича Фонвизина Евдокии Федоровны Фонвизиной (Пущиной) (см.: Глушкова В. Г. Усадьбы Подмосковья. История, владельцы, жители, архитектура. Исторический путеводитель. М.: Вече, 2011. 560 с.). В 1852 г. сопровождала Ивана Александровича в его поездке в Тобольск. После смерти сестры жила у ее мужа (Руммель В. В., Голубцов В. В. Родословный сборник русских дворянских фамилий: в 2 т. СПб.: Изд-е А. С. Суворина, 1887. T. 2. C. 313).

С. 63. ...Александру Өедоровну привптствую - Имеется в виду Федоровна Пущина Александра - сестра Екатерины Федоровны Пущиной (Руммель В. В., Голубцов В. В. Родословный сборник русских дворянских фамилий: в 2 т. СПб.: Изд-е А. С. Суворина, 1887. T. 2. C. 313).

С. 63. ...Мих<аилу> Иван<овичу> усердно кланяюсь - Имеется в виду Михаил Иванович Пущин (13.11.1800-25.05.1869) - брат Ивана Ивановича Пущина (1798-1859), женившегося в 1857 г. на овдовевшей Н. Д. Фонвизиной (см.: Глушкова В. Г. Усадьбы Подмосковья. История, владельцы, жители, архитектура. Исторический путеводитель. М.: 
Вече, 2011. 560 с.). 13 декабря 1825 г. оказался на совещании декабристов у Рылеева и выступил против организации восстания. 14 декабря в восстании не участвовал, привел Измайловский полк и Конно-пионерский эскадрон к присяге Николаю I. По показаниям участников восстания был арестован и заключен в Петропавловскую крепость. После суда над декабристами в июне 1826 г. признан виновным и сослан в Сибирь, в Красноярский гарнизонный батальон, вскоре переведен рядовым в Кавказскую армию (Руммель В. В., Голубцов В. В. Родословный сборник русских дворянских фамилий: в 2 т. СПб.: Изд-е А. С. Суворина, 1887. Т. 2. С. 312).

Исследование выполнено по гранту Министерства образования и науки России «Новые источниковедческие и текстологические исследования русской словесности XIX-XX вв.» (№ 34.1126). 